\title{
SMALL AND MEDIUM SCALE ENTERPISES AND INDUSTRIAL GROWTH IN NIGERIA.
}

\author{
Michael A. Ikon \\ Nnamdi Azikiwe University, Awka. \\ Chika Anthonette Chukwu \\ Nnamdi Azikiwe University, Awka.
}

\begin{abstract}
:
Infrastructural constraints in Nigeria militate against efficient performance of Small and Medium Scale Enterprises (SMEs) and adversely affect industrial growth in the country. The objective of this study was to determine the relationship that exists between manufacturing SMEs production and industrial growth in Nigeria. Secondary data was sourced from the Central Bank of Nigeria's Statistical Bulletin and National Bureau of Statistics publications for the period 2002-2016, and regression analysis was used in analysing the data. Findings of the study reveal that manufacturing SMEs' production has a statistically significant relationship with industrial growth in Nigeria. This implies that manufacturing SMEs are capable of accelerating industrial growth through their contributions to the economy. The study, however, advocates more government intervention by facilitating access to congressional funds for SMEs to trigger SMEs increased contributions to growth and industrial growth in Nigeria.
\end{abstract}

Key words: Industrial Growth, Nigeria, Small and Medium Scale Enterprises (SMEs).

\section{INTRODUCTION:}

\subsection{The Background to the Study:}

SMEs make up the largest proportion of businesses all over the world and are hence the engine that drives the world financial system and the stepping stone to industrialisation, both for developing and developed Nations. According to Chea (2009) small industries account for about $88 \%$ of the small scale industries while $12 \%$ is credited to the medium industries in Malaysia.

In Nigeria, SMEs make up about $97 \%$ of the economy; they hence play a very important and major role in the development of the economy through job creation, poverty alleviation and foreign exchange conservation (Imeokparia and Ediagbonya, 2014).

Although SMEs are smaller in size, they are the most important group of enterprises in the economy due to the fact that when all the individual enterprises are combined, they exceed those of the larger companies. SMEs involve very small micro-firms run by one or two persons with very slow growth or no growth, to fast growing medium sized businesses earning millions of dollars with a majority of them employing as many as 250 employees (Fjose et al, 2010). SMEs are also the link between simple industries and highly developed and complex industries and provide a platform for Africa's take-off in development. These industries play an essential role in facilitating development through the provision of inputs and services for industries while at the same time providing direct goods and services to consumers. This makes the SMEs continuously boost the economy leading to the sustainable growth and development of African countries (Fjose et al., 2010).

The need to have a regulatory body to control the activities of the SMEs in the country led to the formation of the Small and Medium Enterprises Development Agency of Nigeria 
(SMEDAN) in 2004 by an Act of Parliament, towards the realization of the goals and objectives of the SMEs.

The term, industrial growth, has been defined by various scholars in different ways. Industrial growth refers to growth in the industrial sector of a nation's economy. This growth or change must cut across all the sectors of the industry and must be felt in the living standards of the citizens and this is what the SMEs seek to bring to reality.

\subsection{A Statement of the Problem:}

In Nigeria, besides the critical and positive role played by SMEs, SMEs face numerous challenges such as power shortages, lack of capital, poor management skills and competencies, inadequate information, and corruption.

These challenges affect the contributions of the SMEs to the Nigerian Industrial output in particular. This poor performance is evidenced by the fact that most manufacturing enterprises in Nigeria operate well below capacity. Capacity utilization for a product can either be low or high. However, most times, the capacity utilization has been as low as twenty percent (20\%). Only the multinational businesses have succeeded with many SMEs folding up and thus increasing the unemployment situation in the country and resulting in a high crime rate (Imeokparia and Ediagbonya, 2014).

The Nigerian government, in the Nigerian Vision 20:2020 document, has imagined an environment in which small and medium scale enterprises would contribute to the national product and generate $60-70 \%$ employment with sustainable growth, and a low mortality rate for businesses. All the immense awareness and support given to the SMEs relate to the commonly acclaimed fact that SMEs are job and wealth creators. It has, however, been worrisome that despite the incentives, policies, programmes and support aimed at bolstering the SMEs, they have performed rather below expectation in Nigeria. This study is therefore conducted in order to determine the relationship that exists between manufacturing SMEs' production and industrial growth in Nigeria.

\subsection{The Objective of the Study:}

The broad objective of the study is to determine the relationship that exists between manufacturing SMEs production and industrial growth in Nigeria.

\subsection{The Research Question:}

To what extent does manufacturing SMEs production affect industrial growth in Nigeria?

\subsection{The Research Hypothesis:}

$\mathbf{H}_{1}$ : That there is a significant, positive relationship between manufacturing SMEs production and industrial growth in Nigeria.

\subsection{The Scope of the Study:}

The study makes use of secondary data on manufacturing SMEs from the Central Bank of Nigeria's (CBN) statistical bulletin and the National Bureau of Statistics publications (NBS) from 2002 to 2016. 


\subsection{REVIEW OF RELATED LITERATURE:}

\subsection{Conceptual Framework:}

\subsubsection{Concept of Small and Medium Scale Enterprises (SMEs):}

The SMEs remain an important sub-sector in a nation's economy. The contributions of the SMEs has been recognized as critical to the development of an economy as they possess great potentials for employment generation, improvement of local technology, output diversification, development of indigenous entrepreneurship and forward integration with large scale industries. (Central Bank of Nigeria, 2018).

The SME, as a concept, does not have a universal definition. The definition of SMEs varies from country to country and even within sectors in the country. However, the metrics commonly used in defining SMEs include the number of employees, revenues, or fixed assets.

The Federal Ministry of Commerce and Industry (2015) defined SMEs as firms with a total investment (excluding cost of land but including capital) of up to 750,000 Naira, and paid employment of up to fifty persons. SMEDAN (2017) defined SMEs based on the following criteria: small scale enterprises are businesses with ten to forty-nine people with an annual turnover of five to forty-nine million naira, while a medium scale enterprise has fifty to one hundred and ninety-nine employees with annual turnover of fifty to four hundred and ninety-nine million Naira.

These definitions also differ from that of Khan and Dalu (2015) who opine that small and medium scale enterprises have long been catalysts for both industrial growth and economic growth of nations in both developed and developing countries, and it plays an important role for employment generation, facilitating economic recovery and national development.

With the increasing number of SMEs in the country, the need to reconcile their policies, programmes and activities became very important and this led to the formation of Small and Medium Scale Enterprises Agency of Nigeria (SMEDAN) in 2004. This agency was established by the government for the sole aim of regulating the activities of SMEs in the country.

\subsubsection{Industrial Growth:}

Industrial growth refers to growth in the industrial sector of a nation's economy. The industrial sector covers a reasonable portion of the GDP. The Industrial sector can further be divided into subsectors such as Mining and quarrying, manufacturing, production, construction, electricity and gas distribution.

However, there are several measures of Industrial Growth in an economy which include:

\section{The Inflation Rate:}

Inflation is an economic situation in which there is a general rise in the prices of goods and services continuously. It can also be defined as 'a continuing rise in prices as measured by an index such as the consumer price index (CBN, 2018).

When inflation occurs in a nation, the currency loses its purchasing power. That is, there will be too much money available for too few goods. However, a situation may arise such that a 
change in an individual price could cause the other prices to rise. An example is petroleum product prices in Nigeria.

Essentially, two types of inflation have been identified.

a. Demand-pull inflation: This is caused by an increase in the conditions of demand. This could be an increase in the ability to buy goods.

b. Cost-push inflation: This arises from conditions that cause supply to decrease. Some of these factors include a rise in the cost of production, an increase in government taxation or a decrease in quantity of goods produced.

\section{Gross Capital Formation:}

According to Ugwuegbe and Uruakpa (2013) capital formation or accumulation refers to the process of amassing or stocking assets of value, the increase in wealth or the creation of further wealth. Capital formation can be differentiated from savings because accumulation deals with increases in the stock of needed real investments, and not all savings are necessarily invested.

The Central Bank of Nigeria (CBN, 2015), defines capital formation as the total change in the value of fixed assets in the economy in addition to fixed assets either for replacing or adding to the stocks it refers to the increase in the fixed capital stocks of the capital formed. However, capital formation has been confused with investment. Investment can be in financial assets, human (capital) development and real assets that can be productive or unproductive.

\section{Capacity Utilization:}

Ugwuegbe and Uruakpa (2013), define capacity utilization as a ratio of the actual level of output to a sustainable maximum level of output, or capacity. The CBN calculates measures of output, capacity and capacity utilization for the nation's industrial sector, which consists of industries within the manufacturing, mining, and production subsectors. The output figures are monthly indices of industrial production, and each industry utilization rate is equal to an output index divided by a related capacity index.

Capacity utilization for a product can either be low or high. When it is low, it means that the demand for SMEs products is low as a result of poor quality or exorbitant prices. This, therefore, means that sales and profits remain low, leading to poor returns on investment. Erratic power supply as well as inadequate infrastructural facilities can also contribute to low capacity utilization of the SMEs in the manufacturing sector in the country.

\section{The Labour Force:}

The Labour force (economically active population or working population) refers to the population that is willing and able to work, including those actively engaged in the production of goods and services (employed) and those who are unemployed. (Agbodike, Igbokwe-Ibeto Umeifekem, 2015).

The labour force of a country as defined by the National Bureau of Statistics (NBS) (2018) is a set of people or citizens of a country who are willing and are able to make available at any given point in time their efforts for gainful employment. The total labour force in Nigeria is made up of all persons aged 15-64 years excluding students, home keepers, retired persons and stay-at-home to work or not interested. 
When the labour force of a country grows with an increasing proportion of youths, employment growth is however inadequate to absorb labour market entrants. As a result, youth are especially affected by unemployment.

\subsection{The Theoretical Framework:}

This study is anchored on the Theory of Constraints (TOC). The theory of constraints (TOC) developed by Goldratt (1990) is a process that is aimed at identifying the most important limiting factors (that is, constraints) and then systematically improving those constraints until they are no longer limiting factors. In manufacturing, the constraints are referred to as bottlenecks.

The theory of constraints assumes that every complex system, including manufacturing processes, consists of multiple linked activities, one of which acts as a constraint upon the entire system.

The five steps in applying the Theory of Constraints (TOC): Identify, Exploit, Subordinate, Elevate, Reapply.

This theory is relevant to the study in that when the five steps of this theory are applied, they enable the manufacturing SMEs to identify the constraints limiting them and then systematically improve those constraints until they are no longer limiting factors.

\subsection{Empirical Review:}

Ogbuanu, Kabuoh, and Okwu (2014) examined the relevance of small and medium enterprises in the growth of the Nigerian economy: a study of manufacturing SMEs. The study employed the time series research design and descriptive method of analysis to investigate the relevance of the manufacturing SMEs in the growth of the Nigerian economy. Data was extracted from relevant publications of the Central Bank of Nigeria (CBN) and National Bureau of Statistics (NBS). Graphs were used to enhance descriptive analysis of data values over time. The results showed that the manufacturing SMEs made sizable contributions to the sustained increases in the Gross Domestic Product, sustained more than 7 per cent share in employment for greater part of the 2002-2012 period and maintained increasing shares in the GDP.

Ilegbinosa and Jumbo (2015) examined Small and Medium Scale Enterprises and Economic Growth in Nigeria from 1975-2012. The main objective of the paper was to examine the impact of SMEs on economic growth in Nigeria. The study polled 84 SMEs for primary data collection, as well as statistical records for years 1975-2012 as secondary data. The ordinary least square, co-integration and error-correction model was used to estimate the data collected during the period of the study. The results show that Availability of Finance to the SMEs showed a positive relationship with economic growth while Interest rate and Inflation rate showed a negative and positive influence on economic growth respectively.

Taiwo, Ayodeji and Yusuf (2012) examined the impact of small and medium enterprises on economic growth and development. A survey method was used to gather data from $200 \mathrm{SME}$ Entrepreneurial officers and Managers from five selected local government areas in Nigeria. Data was collected with a structured questionnaire while the formulated hypothesis was tested using correlation coefficient to determine the respondents' perception of the subject matter. The results of the study therefore revealed that the most common constraints hindering small and medium scale business growth in Nigeria are lack of financial support, poor management, 
corruption, lack of training and experience, poor infrastructures, insufficient profits, and low demand for products and services.

Onwuchekwa, Emele and Onwuchekwa (2017) examined small and medium scale enterprises (SMES) and industrial development of the Onitsha metropolis: A cluster lead approach. The aim of the study was to address SMEs' agglomeration and industrial development in Nigeria (especially on the Small and Medium Enterprises (SMEs) sub-sector in Onitsha metropolis of Anambra State). The study was anchored on the Porter's Diamond Model of Cluster Determinants. A descriptive survey design was adopted for the study. The questionnaire was used in collecting data for the study and was based on the 5 Likert-type (point) scale technique. The Pearson Product-Moment Correlation Coefficient statistical tool was used to test the research hypothesis. The result obtained from the findings indicated that government policies, support and institutional knowledge transfer to SMEs agglomeration positively correlate with SMEs industrial development in the Onitsha metropolis.

Otalu and Keji (2015) carried out a study on the determinants of industrial sector growth in Nigeria. The study made use of the following variables as major determinants of industrial growth in Nigeria; capital (proxied by gross capital formation), labour (proxied by total labour force in the industrial sector) the exchange rate, education (proxied by school enrolment), the inflation rate, capacity utilization, trade openness and electricity generation. Co-integration and the error correction model were adopted and the results showed that all the identified determinants have more of a permanent effect on industrial output than transitory effect. Both labour and capital have significant impact; the exchange rate shows a positive and significant impact indicating that currency appreciation might be inimical to the growth of the industrial sector.

Anane, Cobbinah and Manu (2013) examined the role of microfinance institutions in the sustainability of small and medium scale enterprises in rural Ghana. The simple random sampling method was used to select the 93 SMEs owners/heads for the survey and interviews in 9 communities in the District were conducted. The survey and interview data were synchronized and refined through focus group discussion and consultative meetings organised for the various categories of SMEs and the banks respectively.

Nuwagaba and Nzewi (2013) examined the major environmental constraints on growth of selected micro and small enterprises (MSEs) in Mbarara Municipality, Uganda. The aim of the study was to examine the extent to which the growth of MSEs is associated with environmental constraints. The stratified random sampling technique was used with a sample of 60 MSEs. They included the fabrication industry, Milling industry, carpentry and small roadside shops. A questionnaire was developed for data collection purposes mainly from relevant MSE's literature for the period October 2011 to February 2012 in Mbarara Municipality. The results revealed that MSEs' growth potential is negatively affected by limited access to productive resources (finance and business services), by high taxes, lack of market access, erratic and costly electricity, lack of infrastructure, lack of human resources, and competitive practices that were dysfunctionally imitative rather than innovative.

Eke (2010) carried out an investigative study on the relevance of small and medium scale enterprises to Nigeria's economic development. The study was centered on financing small and medium scale enterprises for economic development. The overall objective of the study was to seek for improved or new methods of financing SMEs for improved performance which would 
in turn, lead to economic growth and development of the nation. The main data collection instruments were a structured questionnaire and personal interviews. The data collected was presented in tables as frequency distribution and analyzed with percentages and frequencies. The sign test and Pearson product moment correlation coefficient were used to test the hypothesis. The results of the study showed that small and medium scale enterprises were underfinanced and various measures were suggested to improve the funding status including direct government intervention in financing.

Quartey, Turkson, Abor \& Iddrisu (2017) carried out a study on Financing the growth of SMEs in Africa, and the constraints to SME financing within ECOWAS. The study made an attempt to provide some understanding of SMEs' access to finance within the West African sub-region with particular interest in establishing whether there are similarities and/or differences in the determinants of SMEs access to finance across countries in Sub-Saharan Africa. Data from the World Bank's Enterprise Survey data set were used to examine the determinants of access to finance both at the sub-regional level and at the country-level. The data obtained was analysed using the regression analysis. Findings revealed that, at the sub-regional level, access to finance is strongly determined by factors such as firm size, ownership, strength of legal rights, depth of credit information, firm's export orientation and the experience of the top managers.

\section{A Gap in Knowledge:}

The reviewed literature showed that most researchers have attempted to study SMEs and their contributions to both industrial and economic growth and development. However, from all the empirical work reviewed in this study, none of them primarily focused on the manufacturing SMEs' production and its effect on industrial growth in Nigeria. Consequently, this study empirically studied the manufacturing SMEs' production and its effects on industrial growth in Nigeria.

\subsection{RESEARCH METHODOLOGY:}

\subsection{Research Design:}

The study made use of the simple prediction design using the co-efficient of determination to predict the variations among the variables of the study.

\subsection{Method of Data Collection:}

The secondary data was sourced from the Central Bank of Nigeria's statistical bulletin and the National Bureau of Statistics publications for the period 2002-2016. The method of data collection was by extracting time series figures from the publications of the above bodies.

\subsection{Method of Data Analysis:}

The regression analysis was used to determine the relationship that exists between the variables under study.

\subsection{Model Specification:}

The relationship between the dependent and the independent variables was established as follows:

$\mathrm{IG}=\mathrm{f}\left(\mathrm{GDP}, \mathrm{CEMPT}\right.$ SSGDP, CSEXP, MC, CSME, $\left.\mathrm{e}_{\mathrm{t}}\right) \ldots(1)$

Mathematically, the equation becomes:

$\mathrm{IG}=\mathrm{ao}+\mathrm{a}_{1} \mathrm{GDP}+\mathrm{a}_{2} \mathrm{CEMPT}+\mathrm{a}_{3} \mathrm{SSGDP}+\mathrm{a}_{4} \mathrm{CSEXP}+\mathrm{a}_{5} \mathrm{MC}+\mathrm{a}_{6} \mathrm{CSME}+\mathrm{e}_{\mathrm{t}} \ldots$ (2)

Specifying equation 2 in $\log$ form, the equation now becomes 
$\log \quad \mathrm{IG}=\quad \log \quad \mathrm{a}_{0}+\mathrm{a}_{1} \operatorname{LogGDP}+\mathrm{a}_{2} \operatorname{LogCEMPT}+\mathrm{a}_{3} \log S S G D P+\mathrm{a}_{4} \log C S E X P+$ $\mathrm{a}_{5} \log \mathrm{M}_{2}+\mathrm{a}_{6} \operatorname{LogCSEM}+\mathrm{e}_{\mathrm{t}} \ldots$..(3)

Where:

IG= Industrial Growth

GDP $=$ Gross Domestic Product

$\mathrm{CEMPT}=\mathrm{SME}$ contribution to Employment

SSGDP $=$ Small Scale Gross Domestic Product

$\mathrm{CSEXP}=\mathrm{SME}$ Contribution to Export

$\mathrm{MC}=$ Money Supply

$\mathrm{CSME}=$ Credit to SMEs

$\mathrm{e}_{\mathrm{t}}=$ Error or Stochastic term

\subsection{DATA PRESENTATION AND ANALYSIS:}

\subsection{Data Presentation and Analysis}

Dependent Variable: IG

Method: Least Squares

Sample: 2002-2016

Included observations: 15

\begin{tabular}{lllll}
\hline \hline Variable & Coefficient & Std. Error & t-Statistic & Prob. \\
\hline \hline C & 72.80741 & 23.41244 & 3.109774 & 0.0145 \\
GDP & 0.000154 & 0.000415 & 0.371729 & 0.7197 \\
CEMPT & -3.363032 & 1.285670 & -2.615782 & 0.0309 \\
SSGDP & -0.003705 & 0.003056 & -1.212168 & 0.2600 \\
CSEXP & -0.483089 & 0.472852 & -1.021650 & 0.3368 \\
MC & 0.001423 & 0.000582 & 2.443549 & 0.0403 \\
CREDIT TO SMES & -0.002342 & 0.001740 & -1.345677 & 0.2153 \\
\hline \hline R-squared & 0.793200 & Mean dependent variable & 12.40200 \\
Adjusted R-squared & 0.638100 & S.D. dependent variable & 7.391304 \\
S.E. of regression & 4.446472 & Akaike info criterion & 6.126824 \\
Sum squared resid & 158.1689 & \multicolumn{2}{c}{ Schwarz criterion } & 6.457247 \\
Log likelihood & -38.95118 & \multicolumn{2}{c}{ Hannan-Quinn criter. } & 6.123304 \\
F-statistic & 5.114114 & \multicolumn{2}{c}{ Durbin-Watson stat } & 1.157728 \\
Probability(F-statistic) & 0.019139 & & \\
\hline \hline
\end{tabular}

The Constant term is 5.562913 and it is statistically significant at 0.0145 percent signifying that the model can be used to make decisions.

The coefficient of determination $\left(\mathrm{R}^{2}\right)$ is .793200 which indicates that a $79 \%$ variation in the dependent variable is accounted for by changes in the independent variables. The F-statistics is 5.114114 with the Probability of F-statistic 0.019139 indicating that there is a statistically significant relationship between the variables under study. 
Dependent Variable: GDP

Method: Least Squares

Sample: 2002-2016

Included observations: 15

\begin{tabular}{lllll}
\hline \hline Variable & Coefficient & Std. Error & t-Statistic & Prob. \\
\hline \hline C & 15853.40 & 18061.43 & 0.877749 & 0.4029 \\
CEMPT & -369.6298 & 1026.034 & -0.360251 & 0.7270 \\
SSGDP & 3.202124 & 2.212542 & 1.447260 & 0.1817 \\
CSEXP & -82.67050 & 379.0719 & -0.218087 & 0.8322 \\
MC & 0.637997 & 0.416916 & 1.530278 & 0.1603 \\
CREDIT TO SMES & 2.355234 & 1.157714 & 2.034383 & 0.0724 \\
\hline \hline R-squared & 0.991325 & Mean dependent variable & 50893.57 \\
Adjusted R-squared & 0.986506 & S.D. dependent variable & 30767.18 \\
S.E. of regression & 3574.019 & Akaike info criterion & 19.48994 \\
Sum squared resid & $1.15 E+08$ & Schwarz criterion & 19.77316 \\
Log likelihood & -140.1746 & Hannan-Quinn criter. & 19.48693 \\
F-statistic & 205.7007 & Durbin-Watson stat & 1.342005 \\
Probability (F-statistic) & 0.000000 & & & \\
\hline
\end{tabular}

The coefficient of determination $\left(\mathrm{R}^{2}\right)$ is 0.991325 which implies that a $99 \%$ change in the dependent variable is as a result of changes in the independent variables. The F-statistic is 205.7007 and the probability of F-statistic 0.000000 shows that there is a statistically significant relationship between SMEs and industrial growth in Nigeria.

\subsection{Discussion of Findings:}

The study revealed that there is a statistically significant relationship between SMEs and industrial growth in Nigeria. This shows that SMEs actually have an impact on industrial growth in Nigeria. The finding aligns with the finding of Ogbuanu, Kabuoh, and Okwu (2014) who examined the relevance of small and medium enterprises in the growth of the Nigerian economy using the manufacturing SMEs. It was discovered that the manufacturing SMEs which made sizable contributions to the sustained increases in gross domestic product sustained more than 7 per cent share in employment for the greater part of the 2002-2012 period and maintained increasing shares in the GDP.

\subsection{Conclusion:}

Drawing from the insights of the findings, the study concludes that manufacturing SMEs have a significant positive relationship with industrial growth in Nigeria. This implies that manufacturing SMEs are capable of accelerating industrial growth through their contributions to the economy.

\subsection{Recommendation/Advocacy:}

The authors advocate more government intervention in facilitating access to congressional funds by SMEs to trigger off SMEs sustainable growth and industrial growth in Nigeria. 


\section{References}

Agbodike, F., Igbokwe-Ibeto, J. \& Umeifekem, U. (2015). Youth Unemployment and Labour Productivity in Nigeria: The Nexus. Journal of Research and Development, 2 (8), 1428.

Anane, G., Cobbinah, P. \& Manu, J. (2013). Sustainability of Small and Medium Scale Enterprises in Rural Ghana: The Role of Microfinance Institutions. Asian Economic and Financial Review, 3(8), 1003-1017.

CBN (2010). Guidelines for N200 Billion SME Credit Guarantee. Abuja: Development Finance Department, Central Bank of Nigeria.

CBN (2018) Central Bank of Nigeria

Chea, P. (2009). Relationship between Entrepreneurs Value, Firm Financing, Market Practices \& Growth Performance of Small-Medium Enterprises in Cambodia. PhD Thesis, University of Utara, Malaysia, Sintok, Kedah, Malaysia.

Eke, R. (2010). The Relevance of Small and Medium Scale Enterprises to Nigeria's Economic Development: An Investigation. M.Sc Thesis, Nnamdi Azikiwe University, Awka, Nigeria.

Fjose, S., Grunfeld, L. A. \& Green, C. (2010). SMEs and growth in Sub-Sahara Africa: Identifying SME Role and obstacles to SME growth. MENON-Publication, 14, 1-28.

Ilegbinosa, I. \& Jumbo, E. (2015). Small and Medium Scale Enterprises and Economic Growth in Nigeria: 1975-2012. International Journal of Business and Management, 10 (3), 203216.

Imeokparia, P. \& Ediagbonya, K (2014). Small and Medium Scale Enterprises (SMEs): A Catalyst in Promoting Economic Development in Nigeria. Journal of Education and Practice, 5 (33), 92-94.

Khan, J. G. \& Dalu, R. S. (2015). Role of Small \& Medium Enterprises in Industrial Development of Vidarbha Region. International Journal of Engineering Technology, Management and Applied Sciences, 3 (7).

Nuwagaba, A. \& Nzewi, H. (2013). Major Environmental Constraints on Growth of Micro and Small Enterprises in Uganda: A Survey of Selected Micro and Small Enterprises in Mbarara Municipality. International Journal of Cooperative Studies, 2(1), 26-33.

Ogbuanu, B., Kabuoh, M \& Okwu, A. (2014) Relevance of Small and Medium Enterprises in the Growth of the Nigerian Economy: A Study of Manufacturing SMEs. International Journal of Advanced Research in Statistics, Management and Finance, 2 (1), 180-191.

Onwuchekwa F., Emele, E., \& Onwuchekwa, J. (2017). Small and Medium Scale Enterprises (SMES) and Industrial Development of Onitsha Metropolis: A Cluster Lead Approach. International Journal of Economics and Business Management, 3 (10), 64-77. 
Otalu, J. \& Keji, S. (2015). An Assessment of the Determinants of Industrial Sector Growth in Nigeria. Journal of Research in Business and Management, 3(7), 1-9.

Quartey, P., Turkson E., Abor, J, Iddrisu, A. (2017). Financing the growth of SMEs in Africa: What are the contraints to SME financing within ECOWAS? Review of Development Finance, 7, 18-28.

Taiwo, M., Ayodeji, A. \& Yusuf, B. (2012). Impact of Small and Medium Enterprises on Economic Growth and Development. American Journal of Business and Management, $1(1), 18-22$.

Ugwuegbe, U. \& Uruakpa, P. (2013). The Impact of Capital Formation on the Growth of Nigerian Economy, Research Journal of Finance and Accounting, 4 (9), 36-42. 


\section{APPENDIX}

\begin{tabular}{|c|c|c|c|c|c|c|c|c|c|c|c|c|c|}
\hline Year & $\begin{array}{l}\text { GDP } \\
(\mathbf{N}, \\
\text { millions })\end{array}$ & $\begin{array}{l}\text { CEMPT } \\
(\%)\end{array}$ & $\begin{array}{l}\text { SSGDP } \\
(\mathbf{N}, \text { million })\end{array}$ & $\begin{array}{l}\text { CSEXP } \\
(\%)\end{array}$ & $\begin{array}{l}\left(\mathrm{M}_{2} /\right. \\
\text { GDP) } \\
(\%)\end{array}$ & $\begin{array}{l}\text { (CPS/ } \\
\text { GDP) } \\
(\%)\end{array}$ & $\begin{array}{l}\text { Money } \\
\text { Supply }\end{array}$ & $\begin{array}{l}\text { Credit } \\
\text { to SMEs }\end{array}$ & $\begin{array}{l}\text { SSEXP } \\
\text { (N, } \\
\text { millions) }\end{array}$ & $\begin{array}{l}\text { Total } \\
\text { Population }\end{array}$ & $\begin{array}{l}\text { CB } \\
\text { Loan } \\
\text { to SMEs }\end{array}$ & ASI & MC \\
\hline 2002 & 11332.25 & 12.52 & 1127.23 & 36.50 & 13.29 & 8.21 & 1505.96 & 930.49 & 85.47 & 128666700 & 233.47 & 12137.70 & 764.90 \\
\hline 2003 & 13301.56 & 11.73 & 1304.07 & 38.40 & 14.68 & 8.24 & 1952.92 & 1096.54 & 81.66 & 131972500 & 294.31 & 20128.94 & 1359.30 \\
\hline 2004 & 17321.30 & 9.47 & 1516.05 & 41.20 & 12.31 & 8.21 & 2131.82 & 1421.66 & 74.85 & 135393600 & 332.11 & 23844.50 & 2112.50 \\
\hline 2005 & 22269.98 & 10.09 & 1778.73 & 40.60 & 11.85 & 8.26 & 2637.91 & 1838.39 & 105.58 & 138939500 & 352.04 & 24085.80 & 2900.06 \\
\hline 2006 & 28662.47 & 12.56 & 2082.49 & 37.90 & 13.25 & 7.99 & 3797.91 & 2290.62 & 119.71 & 140431790 & 445.79 & 33189.30 & 5120.90 \\
\hline 2007 & 32995.38 & 13.33 & 2401.19 & 39.40 & 15.54 & 11.15 & 5127.40 & 3680.09 & 68.68 & 144998281 & 487.58 & 57990.20 & 13181.69 \\
\hline 2008 & 39157.88 & 9.81 & 2761.55 & 30.70 & 20.45 & 17.73 & 8008.20 & 6941.38 & 117.71 & 149713264 & 932.80 & 31450.78 & 9562.97 \\
\hline 2009 & 44285.56 & 7.92 & 3170.82 & 29.20 & 21.25 & 20.66 & 9411.11 & 9147.42 & 115.87 & 154581566 & 993.46 & 20827.17 & 7030.84 \\
\hline 2010 & 54612.26 & 7.22 & 3578.64 & 28.70 & 20.21 & 18.60 & 11034.94 & 10157.02 & 105.72 & 159608173 & 987.64 & 24770.52 & 9918.21 \\
\hline 2011 & 62980.40 & 6.56 & 4527.45 & 31.40 & 19.33 & 16.93 & 12172.49 & 10660.07 & 244.23 & 164798232 & 1053.21 & 20730.63 & 10275.34 \\
\hline 2012 & 71713.94 & 5.42 & 5588.82 & 33.60 & 19.38 & 20.43 & 13895.39 & 14649.28 & 153.55 & 170157060 & 1068.34 & 28078.81 & 14800.94 \\
\hline 2013 & 80092.56 & 5.24 & 7233.32 & 34.50 & 18.93 & 19.67 & 15160.29 & 15751.84 & 160.86 & 175690143 & 1179.69 & 41329.19 & 19077.42 \\
\hline 2014 & 89043.62 & 5.12 & 8685.43 & 36.03 & 19.86 & 19.24 & 17680.52 & 17128.98 & 187.49 & 181403148 & 1647.45 & 34657.15 & 16875.10 \\
\hline 2015 & 94144.96 & 4.58 & 8973.77 & 38.28 & 20.08 & 19.84 & 18901.30 & 18675.47 & 189.66 & 187301926 & 1736.19 & 28642.25 & 17003.39 \\
\hline 2016 & 101489.49 & 3.39 & 8903.24 & 38.79 & 21.29 & 20.77 & 21607.68 & 21082.72 & 280.21 & 193392517 & 2215.74 & 26874.62 & 16185.73 \\
\hline
\end{tabular}


Ikon \& Chukwu

\begin{tabular}{|c|c|c|c|c|c|c|c|c|}
\hline Year & $\begin{array}{l}\text { Inflation } \\
\text { Rate }\end{array}$ & $\begin{array}{l}\text { Exchange } \\
\text { Rate }\end{array}$ & $\begin{array}{l}\text { Cap } \\
\text { Utilization }\end{array}$ & GCF & $\begin{array}{l}\text { Labour Force } \\
(\%)\end{array}$ & $\begin{array}{l}\text { Labour } \\
\text { Force }\end{array}$ & $\operatorname{IG}(\%)$ & Change in SSGDP \\
\hline 2002 & 12.88 & 113.00 & 54.90 & 499.68 & 31.03 & 39925510 & 13.56 & 176.84 \\
\hline 2003 & 14.03 & 127.00 & 56.50 & 865.88 & 31.00 & 40906810 & 13.98 & 211.98 \\
\hline 2004 & 15.00 & 138.71 & 55.70 & 863.07 & 30.83 & 41748450 & 14.77 & 262.68 \\
\hline 2005 & 17.86 & 141.93 & 54.80 & 804.40 & 30.84 & 42853740 & 14.59 & 303.76 \\
\hline 2006 & 8.23 & 129.32 & 53.30 & 1546.53 & 31.27 & 43907800 & 13.27 & 318.70 \\
\hline 2007 & 5.39 & 121.39 & 53.38 & 1936.96 & 31.06 & 45036270 & 13.05 & 360.36 \\
\hline 2008 & 11.58 & 137.65 & 53.84 & 2053.01 & 30.88 & 46230560 & 12.91 & 409.27 \\
\hline 2009 & 12.54 & 153.48 & 58.92 & 3050.58 & 30.72 & 47480440 & 11.40 & 409.82 \\
\hline 2010 & 13.70 & 154.57 & 55.82 & 2387.33 & 30.56 & 48780750 & 20.96 & 948.80 \\
\hline 2011 & 10.80 & 163.30 & 55.14 & 2366.45 & 30.38 & 50068830 & 18.99 & 1061.38 \\
\hline 2012 & 12.20 & 159.26 & 56.22 & 2584.07 & 30.22 & 51415820 & 22.74 & 1644.50 \\
\hline 2013 & 8.50 & 171.40 & 57.70 & 3131.03 & 30.07 & 52823720 & 16.72 & 1452.11 \\
\hline 2014 & 8.05 & 188.45 & 56.75 & 3653.81 & 29.91 & 54261140 & 3.21 & 288.34 \\
\hline 2015 & 9.55 & 199.20 & 60.50 & 3535.51 & 29.79 & 55789430 & -0.79 & -70.54 \\
\hline 2016 & 18.55 & 300.76 & 54.00 & 3345.58 & 29.66 & 57352350 & -3.33 & -8903.24 \\
\hline
\end{tabular}

